\title{
THE EFFECT STOCK LIQUIDITY TO CASH DIVIDEND FOR NON-FINANCE COMPANY LISTED ON BEI IN 2012 - 2016
}

\author{
Arif Herlambang \\ Jurusan Manajemen Fakultas Bisnis dan Ekonomika \\ arif_herlambang@staff.ubaya.ac.id \\ Putu Anom Mahadwartha \\ Jurusan Manajemen Fakultas Bisnis dan Ekonomika \\ anom@staff.ubaya.ac.id \\ Stefan Adi Christianto \\ Jurusan Manajemen Fakultas Bisnis dan Ekonomika
}

\begin{abstract}
This research aims to analyze factors of stock liquidity, size, profitability, growth, leverage, and cash which affect cash dividend. Independent variable such as stock liquidity, size, profitability, growth, leverage, and cash which affect cash dividend. This research use quantitative approach by using multiple linier regression. The sample of this research is the non-financial company that listed in IDX (Indonesia Stock Exchange) for period of 2012 to 2016. Final samples which are used in this research were 78 business entities with 390 observations. Based on this research, the result show that stock liquidity, and growth give positive effect to cash dividend. size, profitability, leverage, and cash give negative effect to cash dividend.
\end{abstract}

Keywords: Cash Dividend, Stock Liquidity, and Informational Effect

\section{Abstrak}

Penelitian ini bertujuan untuk menganalisis faktor stock liquidity, size, profitability, growth, leverage, and cash yang mempengaruhi cash dividend. Variabel independen yang digunakan ialah stock liquidity, size, profitability, growth, leverage, and cash. Penelitian ini menggunakan pendekatan kuantitatif dengan model analisis linier berganda. Penelitian ini menggunakan sampel berupa badan usaha non-keuangan terdaftar di Bursa Efek Indonesia (BEI) yang membagikan dividen kas periode 2012-2016. Jumlah sampel yang digunakan dalam penelitian ini adalah 78 entitas bisnis dengan 390 observasi.

Hasil penelitian menunjukkan bahwa variabel stock liquidity, dan growth berpengaruh positif terhadap cash dividend. Variabel lainnya seperti size, profitability, leverage, dan cash berpengaruh negatif terhadap cash dividend.

Kata kunci: Cash Dividend, Stock Liquidity, and Informational Effect JEL: G35

\section{Research Background}

In the era of globalization, boundaries between countries are decreasing, cooperation in 
trade, transportation, as well as the ease of information flow between countries have made international activities to be very easy. These conditions triggered a fierce competition among business entities both on a local and international scale. In certain cases, both local and international companies compete by showing the increase on their company performance. Company performance can be interpreted as an achievement or a result for the work done by the company. To assess whether a company has good performance or not, there are some indicators to be assessed for; both financial and non-financial. Financial ratios are financial indicators that process company data in order to provide information regarding company's financial state. In general, data formation can be resulted from the company's business processes; as well as market reaction to a certain corporate action taken by the company. Market reaction is the ability of certain information in describing changes in company's condition; while corporate action is related to the company's activities such as stock split, right issue, and dividend payment. Performing a research upon factors that influence corporate action in the capital market is complicated and interesting. The research carried by Jiang et al (2017) looked at the effect of stock liquidity on dividend payment. Stock liquidity describes the level of a stock's trading frequency in the market where information that can be responded by the market is presented (Market reaction). Dividend payment is a certain amount that a company gives in order to make maximinzing shareholders welfare; given in the form of dividend (Corporate action).

Dividend policy including cash dividends or stock dividends is a hot topic in finance (Ye et al, 2015). Cheng et al (2009), Anderson et al (2011), and Nguyen and Wang (2013) in Ye et al (2015) found that dividend distribution varies each year in each industry. Dividends, especially cash dividends, are a portion of profits or funds that the company does not use and for which it has to be distributed to the shareholders with the aim of maximizing shareholders welfare. If the company happened to have a funding source that is not used for investment decisions, then it is only proper to return the excess funds to shareholders through dividends. Knowing the importance of dividends means knowing the importance of dividend policy for shareholders welfare.

Dividend policy is a common financial topic and often used as a subject for a research. Although research regarding dividend policy is often performed, the basic things that affect dividend policy are still very controversial (Booth and Zhou, 2017). Since Miller and Modigliani (1961) in Jiang et al (2017) suggested dividend irrelevance theory, there were many studies and theories stating the existence of factors that could influence company's dividend payment policy; they could oppose the existence of dividends irrelevance theory.

Dividend irrelevance theory proposed by Modigliani and Miller (1961) states that the level of shareholder welfare is formed by the firm's value upon investment opportunities that they have, and the distribution of company's cash flow to dividends will not affect company value. This theory explains that dividend policy is an indipendent policy and it depends only on investment opportunities that the company have. However, a research performed by Booth and Zhou (2017) states that in real life there are effects of transaction costs on institutional and financial structures in U.S, signaling and agency costs, taxes, and legal systems that influence dividend policy. In line with Booth and Zhou (2017), research by Jiang et al (2017) states that dividend irrelevance theory ignores informational effect, whereas informational effect explains that there is information in the dividend distribution carried by the firm. In addition to informational effect, there is a signaling effect which explains that carriying out dividend policy by increasing or decreasing dividend distribution will affect company's image regarding its prospects and a stable growth in the future. There is also a clientele effect that allows companies to attract shareholders with preference upon dividend in accordance with its historical payment. Jiang et al (2017) stated that stock liquidity can reduce information 
asymmetry between insider and outsider party; thus a company will create a dividend policy that will benefit shareholders.

Jiang et al (2017) examined the effect of stock liquidity on dividend payouts. Research in China used dividend payouts as the dependent variable, while Stock Liquidity, Size, ROA, Growth, Leverage, Cash, Top1, as well as Independence as independent variables. The result showed that Stock Liquidity, Size, ROA, and Cash have a positive effect on cash dividends. Whereas Q, and Leverage have a negative effect on cash dividends.

Chen et al (2017) examined gender composition of dividend payouts. Research performed in UK used dividend payouts as the dependent variable, while Leverage, Tobins Q, ROA, Cash, Assets as independent variables. The results showed ROA, and Cash has a positive effect on cash dividends. While Leverage, Tobins Q, and Asset has a negative effect on cash dividends.

Shamsabadi et al (2016) examined corporate governance and dividend distribution strategies. Research in Australia used dividend payout ratio as the dependent variable, while Firm size, Profitability, Leverage, Growth opportunities, and Cash as independent variables. The results showed that Firm size, Profitability, Leverage has a positive effect on cash dividends. Whereas Growth opportunities and Cash has a negative effect on cash dividends.

Banerjee et al (2007) examined the liquidity of stock market against cash dividend policies. Research at U.S used dividend payout ratio as the dependent variable, while Stock liquidity, Earning before interest and taxes, market to book ratio, and asset growth as independent variables. The results showed that Earning before interest and taxex have a positive effect on cash dividends. While liquidity, market to book ratio, and asset growth have a negative effect on cash dividends.

Table 1.1. Shows the influence of factors that are affecting cash dividend variable. The criteria in selecting independent variable are those variables that were used in two studies minimumly. Shall a variable does not meet the requirement; that variable will be eliminated until an independent variable is obtained for this research.

Dividend policy including cash dividends is a hot topic in finance (Ye et al, 2015). Cheng et al (2009), Anderson et al (2011), and Nguyen and Wang (2013) in Ye et al (2015) found that dividend distribution varies each year in each industry.

Table 1

Result of Several Researches that Tested Cash Dividend

\begin{tabular}{|l|l|l|}
\hline $\begin{array}{l}\text { Researcher } \\
\text { (Year) }\end{array}$ & $\begin{array}{l}\text { Independent and Control } \\
\text { Variables }\end{array}$ & Research Result \\
\hline Jiang et al (2017) & $\begin{array}{l}\text { Stock Liquidity, Size, ROA, } \\
\text { Growth, Leverage, Cash, } \\
\text { Top1, Independence }\end{array}$ & $\begin{array}{l}\text { Stock Liquidity, Size, ROA, } \\
\text { and Cash have a positive } \\
\text { effect, while Q and } \\
\text { Leverage have a negative } \\
\text { effect. }\end{array}$ \\
\hline Chen et al (2017) & $\begin{array}{l}\text { Leverage, Tobin's Q, ROA, } \\
\text { Cash, Asset }\end{array}$ & $\begin{array}{l}\text { ROA and Cash have a } \\
\text { positive effect, while } \\
\text { Leverage, Tobin's Q, and } \\
\text { Asset has a negative effect. }\end{array}$ \\
\hline $\begin{array}{l}\text { Shamsabadi et al } \\
(2016)\end{array}$ & $\begin{array}{l}\text { Firm size, Profitability, } \\
\text { Leverage, Growth } \\
\text { opportunities, Cash }\end{array}$ & $\begin{array}{l}\text { Firm size, Profitability, and } \\
\text { Leverage have a positive } \\
\text { effect, while Growth } \\
\text { opportunities and Cash have } \\
\text { a negative effect }\end{array}$ \\
\hline
\end{tabular}




\begin{tabular}{|l|l|l|}
\hline Banerjee et al (2007) & $\begin{array}{l}\text { Stock liquidity, Earning } \\
\text { before interest and taxes, } \\
\text { market to book ratio, asset } \\
\text { growth }\end{array}$ & $\begin{array}{l}\text { Earning before interest and } \\
\text { taxex has a positive effect, } \\
\text { while stock liquidity, market } \\
\text { to book ratio and asset } \\
\text { growth have a negative } \\
\text { effect. }\end{array}$ \\
\hline
\end{tabular}

Table 1 shows results of several researches on cash dividend. The criteria in selecting independent variable are those variables that were used in two different researches minimumly.

\subsection{The Effect of Stock Liquidity on Cash Dividend}

Jiang et al (2017) states that there is informational effect of stock liquidity on dividend payment. MM's theory (1961) is considered ignoring informational effect. Kyle (1984) in Jiang et al (2017) states that liquidity can help several parties to obtain information that is not reflected in stock prices. Informational effect allows companies' internal parties to make dividend policies. Research by Banerjee et al (2007) found that Stock liquidity has a significant negative effect on cash dividends. Stock liquidity helps reducing information asymmetry between insider and outsider party. Based on agency theory, a low information asymmetry indicates a control of outside party or principal to the insider or agent to ensure that agent performs business functions in shareholders' best interest. Thus company's value will increase because it has reduced the opportunity of perquisite or unprofitable investment ((Easterbrook, 1984; Jensen, 1986) in (Jiang et al 2017)). In addition, Signaling power of dividend will decrease along with the decrease of information asymmetry in dividends. This will prevent companies from paying dividends (Jabbouri, 2016). Based on description above, the following hypothesis is obtained

H1: Stock liquidity has a negative effect on cash dividend.

\subsection{The Effect of Firm Size on Cash Dividend}

Research by Jiang et al (2017) and Shamsabadi et al (2016) found that Size has a significant positive effect on cash dividends. According to Alli et al (1993) in Abor and Viador (2013) large companies will have more stable cash flows in their finance. Companies with cash flows that are more stable will pay bigger dividend. Based on description above, the following hypothesis is obtained

H2: Size has a positive effect on cash dividend.

\subsection{The Effect of Profitability on Cash Dividend}

Research by Jiang et al (2017) and Shamsabadi et al (2016) found that ROA has a significant positive effect on cash dividends. The status quo does not show a contradiction upon the fact that company's profitability influences dividends payment ((Amidu and Abor, 2006; Baker and Jabbouri, 2016; Fama and French, 2000,2002) in (Jabbouri, 2016)). Companies will tend to increase ammount of dividends paid if there is an increase in their profitability. Based on description above, the following hypothesis is obtained

H3: Profitability has a positive effect on cash dividend.

\subsection{The Effect of Growth on Cash Dividend}


Research carried by Jiang et al (2017) found that Tobin's Q has a significant negative effect on cash dividends. Abor and Bopkin (2010) states that Tobin's Q is used to see investment opportunities. Growth potential consumes a lot of financial resources, thus it will decrease the ammount cash for dividend payment. Based on description above, the following hypothesis is obtained

H4: Growth has a negative effect on cash dividend.

\subsection{The Effcet of Leverage on Cash Dividend}

Research carried by Jiang et al (2017) and Chen et al (2017) found that leverage has a significant negative effect on cash dividends. Jabbouri (2016) states that the higher company's debt gets, the more it will prefer to reduce the amount of dividend payment; this aims to maintain its cash in order to pay debt-holders. In addition, Trade-off theory explains that if a company decides to increase its leverage or increase the proportion of their debt usage, it will increase bankruptcy costs that must be borne by that company (Megginson, 1997). Based on description above, the following hypothesis is obtained

H5: Leverage has a negative effect on cash dividend.

\subsection{The Effect of Cash on Cash Dividend}

Research carried by Jiang et al (2017) and Chen et al (2017) found that Cash has a significant positive effect on cash dividends. Dividend payment requires cash. Bird in hand theory states that in fact, shareholders who feel insecure and doubtful regarding company's ability to generate profits in the future will tend to force the company to pay dividends regardless the opportunities for investment growth. Based on description above, the following hypothesis is obtained

H6:Cash has a positive effect on cash dividend.

Based on the description above, the research's conceptual model is shown in Figure 1.

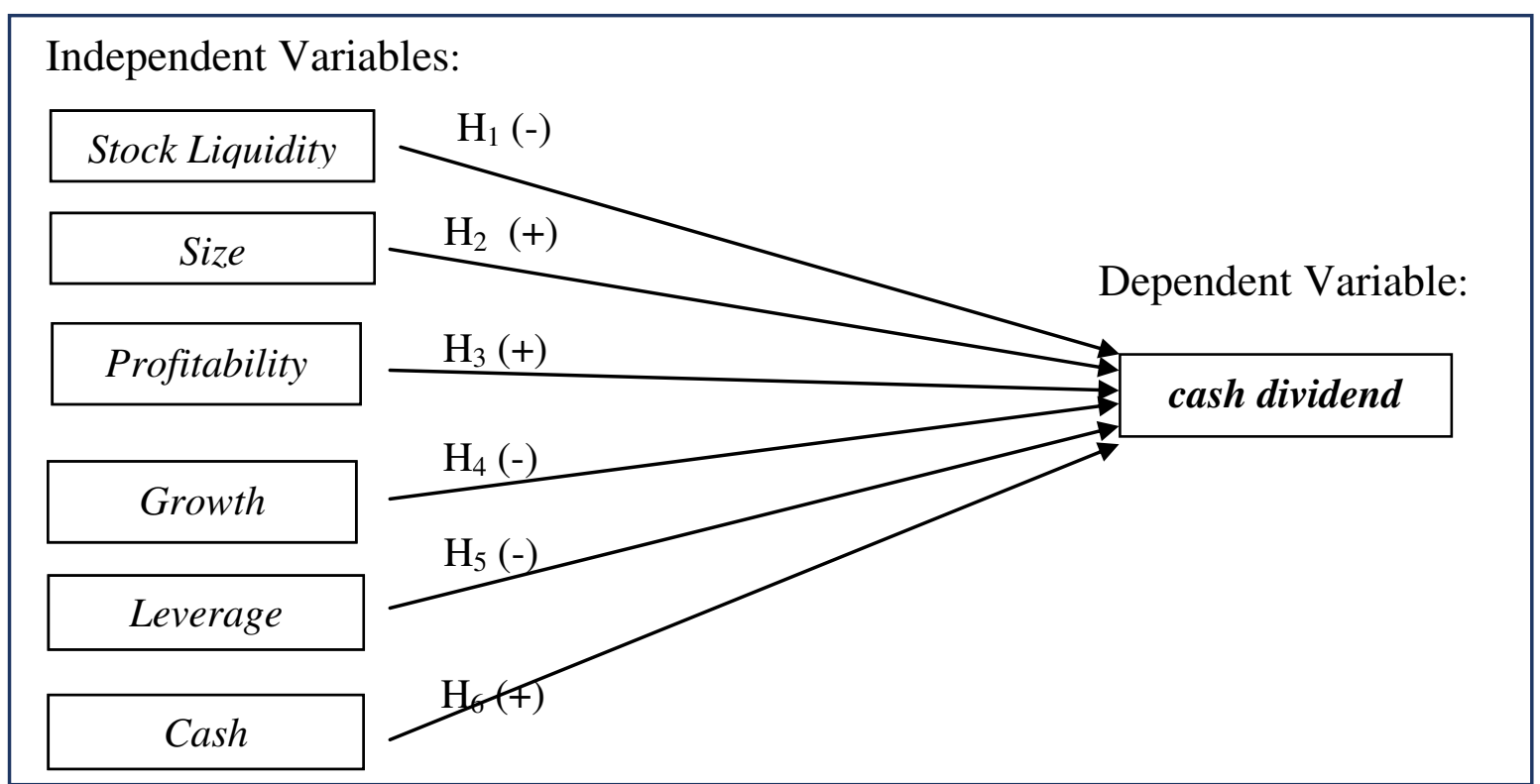




\section{Figure 1 \\ Research Conceptual Model}

\section{Research Method}

This research uses financial statements data of companies on non-financial sector in the Indonesia Stock Exchange that distribute dividends during the period of 2012-2016. Companies used as research objects must meet the following requirements: (a) Registered in Indonesia Stock Exchange during the period of 2012-2016. (b) Issuing audited financial statements for the year ending in December during the period of 2012-2016. (c) Independent variables used for the research must be completely available during the period of 2012-2016. (d) Regularly distributing cash dividends during the period of 2012-2016.

Based on the analysis method and research hypothesis, independent variables used in this research are Stock liquidity, Size, Profitability, Growth, Leverage, and Cash. This research uses data regression method for pooled data or panel data in order to find out the effect of independent variables on the dependent variable directly. Panel data is a combination of crosssection and time-series data. Multiple regressions are used to test for the influence of independent variables on the dependent variable. This research uses Microsoft Excel 2007 program and EViews 8. The data input includes 6 independent variables in order to determine cash dividend for each company in the population. This research uses inferential statistical method that has the purpose of testing the hypothesis.

Variables used in this research are dependent variable and independent variables. Dependent variable in this research is cash dividend, while the independent variables are Stock liquidity, Size, Profitability, Growth, Leverage, and Cash.

$D V E_{i t}=\alpha+\beta_{1} L I Q_{i t}+\beta_{2} S_{I Z E_{i t}}+\beta_{3}$ PROF $_{i t}+\beta_{4} G R O W T H_{i t}+\beta_{5} L E V_{i t}+\beta_{6} C_{A S H}+e$

Notes:

$D V E_{i t}$

$L I Q_{i t}$

$S I Z E_{i t}$

$P R O F_{i t}$

GROWTH ${ }_{i t}$

$L E V_{i t}$

$\mathrm{CASH}_{\text {it }}$

$\propto$

$\beta$

e

: dividend payment on company $i$ in the period of $t$

: the level of stock liquidty on company $i$ in the period of $t$

$:$ the size of company $i$ in the period of $t$

: comparison of net income to total assets on company $\mathrm{i}$ in the period of $\mathrm{t}$

: growth opportunity of company $i$ in the period of $t$

: debt portion on company $i$ in the period of $t$

: cash level on company $i$ in the period of $t$

: constants

: regression coefficient

: error

\section{Result and Discussion}

\subsection{Descriptive Statistics}

The following below is the result of descriptive statistics, which describe the characteristics of this research's object.

Table 3.1

Descriptive Statistics

\begin{tabular}{|l|c|c|c|c|c|c|c|}
\hline & DVE & LIQ & SIZE & PROF & GROWTH & LEV & CASH \\
\hline Mean & 0.402687 & -3.748166 & 29.56385 & 0.352447 & 2.307579 & 0.454641 & 0.138357 \\
\hline Median & 0.328323 & -2.496050 & 29.69323 & 0.299634 & 1.528355 & 0.449899 & 0.115202 \\
\hline Maximum & 2.114977 & -0.049655 & 33.19881 & 1.235939 & 18.64041 & 0.865022 & 0.549898 \\
\hline Minimum & -2.009958 & -14.29286 & 25.71587 & 0.053467 & 0.274465 & 0.075829 & 0.002051 \\
\hline
\end{tabular}




\begin{tabular}{|l|c|c|c|c|c|c|c|}
\hline Std. Dev. & 0.357528 & 3.585384 & 1.488130 & 0.212528 & 2.635228 & 0.175688 & 0.104120 \\
\hline & & & & & & & \\
\hline Jarque-Bera & 1240.277 & 46.41355 & 4.009921 & 149.2509 & 5060.479 & 8.925356 & 141.9113 \\
\hline Probability & 0.000000 & 0.000000 & 0.134666 & 0.000000 & 0.000000 & 0.011531 & 0.000000 \\
\hline & & & & & & & \\
\hline Sum & 157.0481 & -1461.785 & 11529.90 & 137.4543 & 899.9556 & 177.3099 & 53.95904 \\
\hline Sum Sq. Dev. & 49.72428 & 5000.586 & 861.4522 & 17.57034 & 2701.381 & 12.00693 & 4.217175 \\
\hline & & & & & & & \\
\hline Observations & 390 & 390 & 390 & 390 & 390 & 390 & 390 \\
\hline
\end{tabular}

From Table 4.1 it appears that the number of observations in this research was as much as 390 samples. In stock liquidity (LIQ) variable, the max and min values are obtained from TLKM (2016) and MFMI (2015), respectively. In size (SIZE) variable, the max and min values are obtained from ASII (2016) and MFMI (2012), respectively. In profitability (PROF) variable, the max and min values are obtained from MLBI (2013) and ADHI (2016), respectively. In growth (GROWTH) variable, the max and min values are obtained from UNVR (2015) and SMGR (2014), respectively. In leverage (LEV) variable, the max and min values are obtained from FISH (2012) and MFMI (2014), respectively. In Cash (CASH) variable, the max and min values are obtained from DLTA (2016) and ARNA (2016), respectively. In cash dividend (DVE) variable, the max and min values are obtained from PANR (2016) and IMAS (2015), respectively.

\subsection{Regressions Results}

Below are the results of regression test

Table 3.2

Regression Test Results

\begin{tabular}{|c|c|c|c|c|}
\hline Variable & Koefisien & t-Statistic & Probability & Hypothesis \\
\hline $\mathrm{C}$ & 2.623138 & 7.828349 & 0.0000 & \\
\hline LIQ & 0.010340 & 2.756025 & $0.0062 * * *$ & Negative \\
\hline SIZE & -0.062010 & -5.515567 & $0.0000 * * *$ & Positive \\
\hline PROF & -0.696689 & -5.303607 & $0.0000 * * *$ & Positive \\
\hline GROWTH & 0.020366 & 6.561717 & $0.0000 * * *$ & Negative \\
\hline LEV & -0.215086 & -6.218397 & $0.0000 * *$ & Negative \\
\hline CASH & -0.376617 & -17.42547 & $0.0000 * * *$ & Positive \\
\hline R-squared & 0.900014 & \multicolumn{2}{|c|}{ Mean dependent var } & 1.039385 \\
\hline $\begin{array}{l}\text { Adjusted R- } \\
\text { squared }\end{array}$ & 0.872893 & \multicolumn{2}{|c|}{ S.D. dependent var } & 1.163208 \\
\hline $\begin{array}{l}\text { S.E of } \\
\text { reggresion }\end{array}$ & 0.252929 & \multicolumn{2}{|c|}{ Sum squared var } & 19.57570 \\
\hline F-statistic & 33.18576 & \multicolumn{2}{|c|}{ Durbin-Watson stat } & 2.458435 \\
\hline $\begin{array}{l}\text { Prob(F- } \\
\text { statistic) }\end{array}$ & 0.000000 & & & \\
\hline
\end{tabular}

(Source: Processed with Eviews 8)

Notes: $*$ : significance on $10 \%$

$* *$ : significance on $5 \%$

$* * *$ : significance on $1 \%$ 
DVE $=2.623138+0.010340$. LIQ -0.062010. SIZE $-0.696689 . \mathrm{PROF}+0.020366$. GROWTH - 0.215086.LEV - 0.376617.CASH

The equation has constants value of 2.623138.This means shall the value of independent variables are 0 ; the value of cash dividend will be 2.623138 .

The stock liquidity variable has a regression coefficient of 0.010340 . The value shows that there is a positive effect between changes in liquidity and changes in cash dividends. This implies that shall there is an increase or decrease for 1 value of liquidity variable, then cash dividend variable will move accordingly with the value of 0.010340 ; assuming other variables remain the same.

The size variable has a regression coefficient of -0.062010 . The value shows that there is a negative effect between changes in size and changes in cash dividends. This implies that shall there is an increase or decrease for 1 value of size variable, then cash dividend variable will move accordingly in the opposite direction with the value of 0.062010 ; assuming other variables remain the same.

The profitability variable has a regression coefficient of -0.696689 . The value shows that there is a negative effect between changes in profitability and changes in cash dividends. This implies that shall there is an increase or decrease for 1 value of profitability variable, then cash dividend variable will move accordingly in the opposite direction with the value of 0.696689; assuming other variables remain the same.

The growth variable has a regression coefficient of 0.020366 . The value shows that there is a positive effect between changes in growth and changes in cash dividends. This implies that shall there is an increase or decrease for 1 value of growth variable, then cash dividend variable will move accordingly with the value of 0.020366 ; assuming other variables remain the same.

The leverage variable has a regression coefficient of -0.215086 . The value shows that there is a negative effect between changes in leverage and changes in cash dividends. This implies that shall there is an increase or decrease for 1 value of leverage variable, then cash dividend variable will move accordingly in the opposite direction with the value of 0.215086 ; assuming other variables remain the same.

The cash variable has a regression coefficient of -0.376617 . The value shows that there is a negative effect between changes in cash and changes in cash dividends. This implies that shall there is an increase or decrease for 1 value of cash variable, then cash dividend variable will move accordingly in the opposite direction with the value of 0.376617 ; assuming other variables remain the same.

\subsection{F Test Results}

$\mathrm{F}$ test is used to determine whether independent variables altogether have a significant effect on dependent variable. In order to determine this, F test can be run on multiple linear regression model with Fixed Effect Model. If the result of F-statistic test is getting smaller, means the influence of independent variables to dependent variable is getting stronger.

On Table 3.2, it can be seen that F-statistic probability is below $1 \%$; or equal to $0 \%$. Thus, it can be stated that the research variables namely stock liqudity, size, profitability, growth, leverage, and cash altogether have a significant effect on cash dividend at the level of $1 \%$.

\section{4. $\quad t$ Test Results}

$\mathrm{t}$ test is a statistical test that is used to determine the relationship of independent variables to dependent variable partially. Table 3.2 shows a summary of data testing results by regression test. 


\subsubsection{The effect of stock liquidity on cash dividend}

In table 3.2, it is shown that the coefficient of stock liquidity as a variable is 0.010340 and the significance level is 0.0062 . This means that stock liquidity has a significant positive relationship to cash dividends. This finding is supported by the research of Jiang et al (2017), however this finiding is contrary to the research caried by Banerjee et al (2007) which found a negative relationship between stock liquidity and cash dividends.

This research hypothesis states that there is a negative relationship between stock liquidity and cash dividends. The research results show a significant positive relationship which means that stock liquidity is affecting cash dividends in the opposite direction from hypothesis. This condition shows that a type 1 error has occurred. Type 1 error occurs because the research results show that $\mathrm{H}_{0}$ is rejected; although in fact $\mathrm{H}_{0}$ is true.

La Porta et al (1998, 2000a) in Jiang et al (2017) documented low dividend payments in countries with weak legal system and poor accounting standards that are unable to protect minority investors from insiders takeover. Law, regulation, and corporate governance in developing countries are no better than those in developed countries (Jiang et al, 2017). Companies can pay bigger ammount or less dividends in certain periods according to insider's wishes, thus dividend payment policy is rather determined by insider's wishes. In addition, developing countries may have a situation where informations are more opaque or unclear, as well as concentrated ownership structures than developed countries ((Claessens et al, 2000) in (Wasef and Kusumastuti, 2010)). John (2001) in Wasef and Kusumastuti (2010) states that rights obtained by owning shares are the surpervision right, voting right, and right upon cash flow allocation. According to Berkman et al (2009) in Jiang et al (2017) with a high information asymmetry (less liquid firm), controlling shareholders often make use of cash and other resources for personal interests; such as making a transaction agreements with other parties and transfering company assets with unreasonably low prices (Transfer pricing). By using their voting rights, controlling shareholders can easily allocate the firm's resources in the general meeting of shareholders. Thus, there will be a small amount of cash left within the company; and only a small amount of cash that can be distributed into dividends.

\subsubsection{The effect of size on cash dividend}

In table 3.2, it is shown that the coefficient of size as a variable is -0.062010 and the significance level is 0.0000 . This means that size has a significant negative relationship to cash dividends. This finding is supported by the research of Banerjee et al (2007), however this finiding is contrary to the research caried by Jiang et al (2007) which found a positive relationship between size and cash dividends.

This research hypothesis states that there is a positive relationship between size and cash dividends. The research results show a significant negative relationship which means that size is affecting cash dividends in the opposite direction from hypothesis. This condition shows that a type 1 error has occurred. Type 1 error occurs because the research results show that $\mathrm{H}_{0}$ is rejected; although in fact $\mathrm{H}_{0}$ is true.

Large-scale companies tend to have greater debt percentage than smaller companies because those large-scale companies have an easier access to external funding ((D'Auria et al, 1999; Lehnmann and Nueberger, 2000) in (Jabbouri, 2016)). Capital structure or a firm's assets are consist of debt and equity combination. If company's size is increasing because of the increase on its liability, then its obligation to debt-holders will be higher; thus dividend payments will dcecrease.

\subsubsection{The effect of profitability on cash dividend}


In table 3.2, it is shown that the coefficient of profitability as a variable is -0.696689 and the significance level is 0.0000 . This means that profitability has a significant negative relationship to cash dividends. This finding contrary to the research caried by Jiang et al (2007) and Shamsabai et al (2016) which found a positive relationship between profitability and cash dividends.

This research hypothesis states that there is a positive relationship between profitability and cash dividends. The research results show a significant negative relationship which means that profitability is affecting cash dividends in the opposite direction from hypothesis. This condition shows that a type 1 error has occurred. Type 1 error occurs because the research results show that $\mathrm{H}_{0}$ is rejected; although in fact $\mathrm{H}_{0}$ is true.

According to Faccio et al (2005) in Jabbouri (2016), potential for growth spends a lot of financial resources. If the company has a high investment opportunity, it is possible that they will increase their capital expenditure and/or their working capital. The increase in capital expenditure and/or working capital definitely requires financial resources. If the investment opportunities are funded by additional equity, a negative reaction occurs due to the announcement of new equity (Hawawin and Viallet, 1999); thus if a firm's profitability is increasing, it is better for them to hold their income for investment opportunities than to distribute it in the form of dividends.

\subsubsection{The effect of growth on cash dividend}

In table 3.2, it is shown that the coefficient of growth as a variable is 0.020366 and the significance level is 0.0000 . This means that growth has a significant positive relationship to cash dividends. This finding contrary to the research caried by Jiang et al (2007) which found a negative relationship between growth and cash dividends.

This research hypothesis states that there is a negative relationship between growth and cash dividends. The research results show a significant positive relationship which means that growth is affecting cash dividends in the opposite direction from hypothesis. This condition shows that a type 1 error has occurred. Type 1 error occurs because the research results show that $\mathrm{H}_{0}$ is rejected; although in fact $\mathrm{H}_{0}$ is true.

Investors' response to stock increases will have an impact on Tobin's Q increase; Partington (1983) in Jabbouri (2016) ensures that dividend payments are based on investment and growth potential. Signaling effect theory explains companies need to give out signal to investors regarding company's prospects for growth; thus companies tend to give out higher dividends. In addition, Andrianto and Mirza (2016) states that Indonesia is classified as weak market efficiency, whereas not all information are reflected in market prices. To ensure that a high growth potential is reflected in the increase in stock prices and Tobin's Q, companies need to distribute higher dividends to ensure that they are indeed have a high growth potential and capability to pay.

\subsubsection{The effect of leverage on cash dividend}

In table 3.2, it is shown that the coefficient of leverage as a variable is $-0,215086$ and the significance level is 0.0000 . This means that leverage has a significant negative relationship to cash dividends. This finding is supported by the research caried by Jiang et al (2007) which found a negative relationship between leverage and cash dividends.

Jabbouri (2016) states that the higher company's debt gets, the same company will prefer to cut-out or to reduce the amount of dividend paid; this aims to maintain their cash in order to make payments to debt-holders. In addition, Trade-off theory explains that if a company continues to increase its leverage, this action will increase bankruptcy costs that they must bear; shall they continue to increase their debt usage proportion. 


\subsubsection{The effect of cash on cash dividend}

In table 3.2, it is shown that the coefficient of cash as a variable is - 0,376617 and the significance level is 0.0000 . This means that cash has a significant negative relationship to cash dividends. This finding finding is supported by the research caried by Shamsabadi et al (2016), but contrary to the research caried by Jiang et al (2007) which found a positive relationship between cash and cash dividends.

This research hypothesis states that there is a positive relationship between cash and cash dividends. The research results show a significant negative relationship which means that cash is affecting cash dividends in the opposite direction from hypothesis. This condition shows that a type 1 error has occurred. Type 1 error occurs because the research results show that $\mathrm{H}_{0}$ is rejected; although in fact $\mathrm{H}_{0}$ is true.

Damodaran (1999) in Shamsabadi (2016) states that company's dividend policy follows the company's life cycle. During mature growth state, companies with massive cashflows and small investment opportunities will increase their dividend payment. However, if there are a lot of investment opportunities with the potention to generate long-term profits for the company, then they will reduce their dividend payment and allocate their cash for the investment opportunities. In addition, there are several main reasons why companies hold their cash flows; such as transaction motives, security motives, and speculative motives. On speculative motives, companies hold their cash in order to take advantage of business opportunities that might appear unpredictably (Murhadi, 2013, p.16). Companies can transfer their idle cash into marketable securities, which will encourage companies to pay lower dividends.

\subsection{Determination coefficient}

The functions of $\mathrm{R}^{2}$ and adjusted- $\mathrm{R}^{2}$ values are to show how much does the dependent variable can be explained by independent variables. $\mathrm{R}^{2}$ has a weakness, namely that its value will be higher if the number of independent variables is increasing; regardless whether the new independent variable is significant or not. To overcome this, adjusted- $\mathrm{R}^{2}$ is used; whose value will increase if the additional independent variable has a significant effect on the dependent variable.

In table 3.2, the values of $\mathrm{R}^{2}$ and adjusted- $\mathrm{R}^{2}$ are 0.900014 and 0.872893 respectively. Thus, it can be concluded that dependent variable (cash dividend) can be explained well by its independent variables (stock liquidity, size, profitability, growth, leverage, and cash).

\section{Conclusion}

Based on the results of hypothesis testing using F test with Eviews 8 software, it was found that the results of statistical calculations showed $F$ count $=33.18576$ with a probability of $0.000000<0.05$. This means that variables, namely stock liquidity, size, profitability, growth, leverage, and cash altogether have a significant effect on cash dividends. Based on the results of hyphotesis testing using $t$ test, it is obtained that variables, namely stock liquidity, size, profitability, growth, leverage, and cash have a significant effect on cash dividend.

Stock liquidity has a significant positive effect on cash dividends. This is because poor law practice, regulation, governance, and poor environment for the availability of information can cause insiders to easily holding back cashflow for personal interest and hardly detectable by outsiders ((Stiglitz, 2000; Leuz et al, 2003) in (Jiang et al, 2017)). In addition, developing countries have concentrated ownership structures ((Claessens et al, 2000) in (Wasef and Kusumastuti, 2010)) where controlling shareholders use their voting rights and their cash allocation rights to transfer company's assets and having transactions with other parties that will harm the company; as a result, there will be a small amount of cash left within the 
company to be distributed into dividends.

Size has a significant negative effect on cash dividend. This is because large companies can have a higher debt usage than smaller companies ((D'Auria et al, 1999; Lehnmann and Nueberger, 2000) in (Jabbouri, 2016)). Capital structure or a firm's assets are consist of debt and equity combination. If company's size is increasing because of the increase on its liability, then its obligation to debt-holders will be higher; thus dividend payments will dcecrease.

Profitability has a significant negative effect on cash dividend. This happens because generally, a company would choose internal financing over external one; in this case, the intended internal financing is cash flow generated from company's operations. If the investment opportunities are funded by additional equity, a negative reaction occurs due to the announcement of new equity (Hawawin and Viallet, 1999); thus if a firm's profitability is increasing, it is better for them to hold their income for investment opportunities than to distribute it in the form of dividends but having an additional equity to fund the investment.

Growth has a significant positive effect on cash dividends. Andrianto and Mirza (2016) states that Indonesia is classified as weak market efficiency, whereas not all information are reflected in market prices. To ensure that a high growth potential is reflected in the increase in stock prices and Tobin's Q, companies need to distribute dividends to ensure that they are indeed have a high growth potential and capability to pay.

Leverage has a significant negative effect on cash dividends. This is due to the fact that the higher company's debt gets, the same company will prefer to cut-out or to reduce the amount of dividend paid; this aims to maintain their cash in order to make payments to debtholders (Jabbouri, 2016). In addition, Trade-off theory explains that if a company continues to increase its leverage, they will increase bankruptcy costs that they must bear; shall they continue to increase their debt usage proportion.

Cash has a significant negative effect on cash dividends. There are several main reasons why companies hold their cash flows; such as transaction motives, security motives, and speculative motives. On speculative motives, companies hold their cash in order to take advantage of business opportunities that might appear unpredictably (Murhadi, 2013, p.16). Companies can transfer their idle cash into marketable securities, which will encourage companies to pay lower dividends.

\section{References}

Abor, J., Godfred A. Bopkin, 2010, Investment opportunities, corporate finance, and dividend payout policy: Evidence from emerging markets, Studies in Economics and Finance, Vol. 27: 180-194.

Abor, J., Vera Fiador, 2013, Does corporate governance explain dividend policy in SubSaharan Africa?, International Journal of Law and Management, Vol. 55: 201-225.

Andrianto, Y., Adrian Rishad Mirza, 2016, A Testing of Efficient Markets Hypothesis in Indonesia Stock Exchange, Social and Behavioral Sciences, Vol. 219: 99-103.

Bae, J., Sang-Joon Kim, Hannah Oh, 2017, Taming polysemous signals: The role of marketing intensity on relationship between financial leverage and firm performance, Review of Financial Economics, Vol. 33: 29-40.

Banerjee, S., Vladimir A. Gatchev, Paul A. Spindt, 2007, Stock Market Liquidity and Firm Dividend Policy, Journal of Financial and Quantitative Analysis, Vol. 42: 369-398.

Berenson, M. K., et al., 2012, Basic Business Statistics Concept and Aplication $12^{\text {th }} \quad$ Edition Prentice Hall.

Booth, L., Jun Zhou, 2017, Dividend policy: A selective review of results from around the world, Global Finance Journal, Vol. 34:1-15. 
Chen, J., Woon Sau Leung, Marc Goergen, 2017, The impact of board gender composition on dividend payouts, Journal of Corporate finance, Vol. 43: 86-105.

Ghozali, H.I., 2009, Aplikasi Analisis Multivariate dengan Program SPSS, $\quad$ Cetakan IV,

Badan Penerbit Universitas Diponegoro, Semarang.

Gujarati, D.N.,2012, Dasar-dasar Ekonometrika, Terjemahan Mangunsong, $\quad$ R.C.,

Salemba Empat, buku 2, Edisi 5, Jakarta.

Jabbouri, I., 2016, Determinants of Corporate dividend policy in emerging markets: Evidence from MENA stock market, Research in International Business and Finance, Vol. 37: 283-298.

Jiang, F., Yunbiao Ma, Beibei Shi, 2017, Stock liquidity and dividend payouts, Journal of Corporate finance, Vol. 42: 295-314.

Murhadi, W.R., 2013, Analisis Laporan Keuangan, Proyeksi, dan Valuasi Saham, Salemba Empat, Jakarta

Shamsabadi, H.A., Byung-Seong Min, Richard Chung, 2016 Corporate governance and dividend strategy: lessons from Australia, International Journal of Managerial Finance, Vol. 12: 583-610.

Wasef, R.M., Retno Kusumastuti, 2010, Ownership Structure and Performance of Public Companies Listed in Indonesia Stock Exchange, Journal of Administrative Sciences and Organization, Vol. 17: 238-249.

Ye, Z., Zhi Zhang, Songlian Tang, 2015, Stock dividends policy and liquidity of ex ante announcement: The liquidity hypothesis retest, China Finance Review International, Vol. 5: 258-276. 